\section{Selvfølelse og oppmerksomt nærvær - primært for kursveiledere}

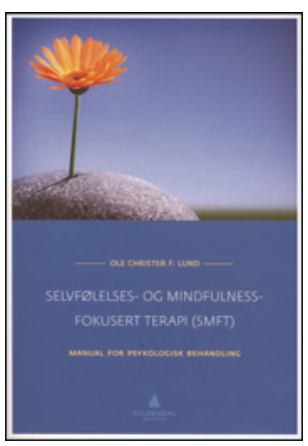

Ole Christer Finset Lund

Selvfølelses- og mindfulness-fokusert terapi (SMFT)

Manual for psykologisk behandling. 223 s, ill.

Oslo: Gyldendal Akademisk, 2013

Pris NOK 365

ISBN 978-82-05-44740-0

Psykolog Ole Christer Finset Lund har to ganske forskjellige hovedformål med denne boken. For det første har han laget en manual for fagfolk som skal lede kurs og grupper - hovedsakelig kurs for foreldre som vil redusere stressnivåene i hverdagen. For det andre ønsker han å beskrive en terapiform han selv har utviklet, kalt selvfølelses- og mindfulness-fokusert terapi (SMFT) til bruk både individuelt og $\mathrm{i}$ gruppesammenhenger.

Etter to innledende kapitler med definisjoner og målsettinger handler de neste fem kapitlene og det siste kapitlet om gjennomføring av stressreduserende kurs for foreldre. De er skrevet som en godt gjennomarbeidet og erfaringsbasert praktisk manual. Det merkes at forfatteren har egen erfaring fra foreldreveiledning, og fra kursvirksomhet innen temaer som oppmerksomt nærvær (mindfulness), stressmestring og foreldrerolle. Man henvises hyppig til forfatterens forrige bok Senk stresset i familielivet. Mindfulness $i$ foreldrerollen (2011) for beskrivelse av den teoretiske kunnskapen bak denne praktiske instruksjonen.

I de to resterende kapitlene beskriver forfatteren SMFT som terapiretning. Her forlater han manualformatet og presenterer den eklektiske integrasjon av selvfølelses- og minfulnessfokuserte terapitilnærminger, i kombinasjon med elementer fra relasjonsorienterte, løsningsfokuserte , narrative, kognitive og atferdsfokuserte retninger som SMFT bygger på. En «intervensjonsstjerne» skal gi terapeuten ledetråder til hvilke intervensjoner som skal brukes ved forskjellige tidspunkter i terapiforløpet. Det påpekes i teksten at denne terapien ikke er forankret forskningsmessig, og disse kapitlene fremstår mer fragmentariske og mindre erfaringsbaserte.

Forfatteren bruker flere pedagogiske grep. «Ti SMFT-prinsipper» lanseres som huskeregler - de fleste av disse er viktige prinsipper for enhver terapiform. Boken er lettlest, med relativt korte underkapitler, noen illustrasjoner og flere faktabokser med oppsummeringer og instruksjoner. Kasuistikker gir gode eksempler - spesielt vedrørende gruppeveiledningen for foreldre.

Boken kunne med fordel hatt en referanseliste etter hvert kapittel istedenfor en felles referanseliste på slutten. Det finnes et appendiks med huskelister som kan lastes ned fra nettet. Via en link til Gyldendal finnes også evalueringsskjemaer for gruppeveiledning og lydfiler med instruksjoner til øvelser.

Oppsummert oppleves hovedsøkelyset i denne boken å være en manual for gjennomføring av kurs i teknikker for foreldre som trenger å mestre en stressende hverdag. Presentasjonen av den eklektiske terapiretningen (SMFT) for individualterapi er fragmentarisk og mindre overbevisende.

\section{Cannabis sett med norske øyne}

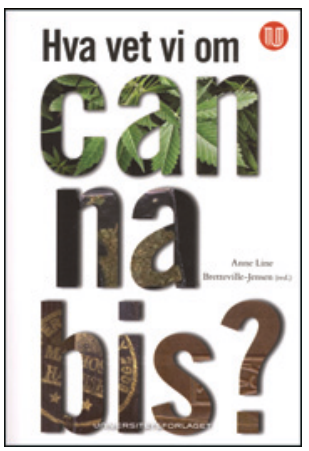

«Hva vet vi om cannabis?» Tittelen vekker nysgjerrighet, og en liten porsjon skepsis. Skal denne pocketboken - med 170 små sider - virkelig dekke alt vi vet om cannabis? Tittelen dekker i hvert fall hele omslaget, og det er jo en god start.

Forfatterne er ti norske rusmiddelforskere som til sammen har faglige røtter i medisin, psykologi, sosiologi, jus og samfunnsøkonomi. I ti kapitler tas ulike temaer opp, som cannabiseffekter, bruksstatistikk, brukerkultur, cannabismarked, skadevirkninger for individ og samfunn samt nasjonal og internasjonal rettspraksis. Hvert kapittel avsluttes med en innrammet boks med hovedpunkter. Språket er fortellende og terminologien stort sett enkel. Flere av kapitlene er illustrert. Samlet bidrar dette til en informativ og lettlest bok, som gjerne kan leses fra perm til perm. Noen kapitler er spesielt leseverdige. Min favoritt er «Bør cannabis bli lovlig?». Alle som har sterke meninger om cannabis - enten man mener det kurerer alt, eller man mener det er roten til alt ondt - bør lese dette kapitlet for å forstå at spørsmålet om liberalisering er komplisert.

Om boken lever opp til den ambisiøse tittelen? Ja, faktisk gjør den det. Den går ikke dypt, men den går dypt nok. Og trass i mylderet av cannabislitteratur som allerede eksisterer, tilfører denne boken noe helt nytt: den er ikke bare på norsk, den er norsk. Vi får forklart hva som kjennetegner den norske cannabiskulturen, det norske bruksmønsteret og den norske cannabislovgivningen, satt i et internasjonalt perspektiv. Å samle denne særnorske kunnskapen på ett sted er et viktig nybrottsarbeid.

Boken kan anbefales til alle som vil lære mer om cannabis, enten man er lege, politi, politiker, lærer, forelder eller cannabisrøyker.

\section{Andreas Austgulen Westin}

Avdeling for klinisk farmakologi

St. Olavs hospital

Trondheim 